\title{
Some Features of the Metastatic Cancer Cells in Prostaglandin Production
}

\author{
Ichiro Nakazawa, Masamoto Iwaizumi* and Kazuo \\ OHUCHI†
}

The Third Department of Internal Medicine, Tohoku University School of Medicine, *the Chemical Research Institute of Non-Aqueous Solutions, and $\dagger$ Department of Biochemistry, Faculty of Pharmaceutical Sciences, Tohoku University, Sendai 980

\begin{abstract}
Nakazawa, I., Imaizumi, M. and Онuchi, K. Some Features of the Metastatic Cancer Cells in Prostaglandin Production. Tohoku J. Exp. Med., 1989, 159 (1), 75-78 - In order to establish metastatic lesions, $2.5 \times 10^{6} \mathrm{AH} 100 \mathrm{~B}$ cells were injected into the left carotid artery of male Donryu rats. Each metastatic nodule in the liver or kidney, $1 \mathrm{~mm}$ or less in diameter, thus obtained was then injected into the peritoneal cavity in which these metastatic cells come to free. About 3 weeks later, each ascites was collected from the rats, while not bloody. Then, cancer cells obtained from each ascites were suspended in Dulbecco's PBS without $\mathrm{Ca}^{2+}$ and $\mathrm{Mg}^{2+}\left(\mathrm{pH}\right.$ 7.2) after washing. Then, $10^{6}$ metastasized or control cancer cells were incubated in $0.1 \mathrm{ml}$ of PBS mentioned above together with $0.1 \mu \mathrm{Ci}$ of $\left(1{ }^{14} \mathrm{C}\right)-\mathrm{AA}$ at $24^{\circ} \mathrm{C}$ for $3 \mathrm{~min}$, respectively. After the extraction procedure, AA metabolites formed were separated by means of TLC, and each TLC plate was subjected to autoradiography. In the metastasized cells, PG production ability was generally accelerated and especially in that of $\mathrm{PGF}_{2 \alpha}$ as compared with that of the control. —— cancer metastasis ; $\mathrm{PG}$ production; $\mathrm{PGF}_{2 \alpha}$; growth factor; promotor
\end{abstract}

Metastasis to other organs is one of characteristics of cancer which makes it difficult to treat cancer patients. Therefore, it is desirable to clarify the mechanism of cancer metastasis in order to cure patients. Fidler (1973a) reported that only $1 \%$ of B16 melanoma cells injected intravenously had survived to form actual pulmonary metastasis. Fidler (1973b) succeeded also in obtaining the highly metastatic strains of B16 melanoma by means of intravenous injection and tissue culture of the metastatic lesions. Bosmann et al. (1973) recognized the biochemical features of the most highly metastatic strain (F10), that is, the change in the electrophoretic mobility, surface glycoprotein, proteases and increasing degradative enzyme as compared with those of low metastatic B16 melanoma

Received August 18, 1989; revision accepted for publication September 6, 1989.

Abbreviations : PG, prostaglandin; AA, arachidonic acid; TX, thromboxane ; TLC, thin-layer chromatography; PBS, phosphate buffered saline. 
strain (F1). Miller et al. (1985) suggested that metastasis of human colonic cancer would be owing to the specific tumor cell phenotypes. Nakazawa et al. (1978) studied lipid-chemical features of metastatic lesions in the liver as compared with that of primary lesions.

In the present work, we deal with some features of the metastatic cancer cells in prostaglandin production.

\section{Materials and Methods}

Animals. Donryu male rats (Nihon Rat Co., Ltd., Urawa) weighing 100 to $120 \mathrm{~g}$ were used. They were fed with a pellet diet, NF (Oriental Yeast Co., Ltd., Tokyo), and tap water freely.

Tumor. AH100B cell kept at the Department of Oncology, the Research Institute for Tuberculosis and Cancer, Tohoku University, was transplanted into the peritoneal cavity of rats. Ascites was collected about 7 days later, while not bloody, and centrifuged at $4^{\circ} \mathrm{C}$ for 5 min $(700 \times g)$. Each sediment was then washed three times with $0.9 \% \mathrm{NaCl}$ solution. Then, $2.5 \times 10^{7}$ cancer cells were suspended in $1 \mathrm{ml}$ of $0.9 \% \mathrm{NaCl}$ solution and each $0.1 \mathrm{ml}$ of the cell suspension was injected into the left carotid artery of rats retrogressively. The cell suspension was also transplanted intraperitoneally to rats as the control. The rats used for cancer metastatic formation were killed 3 weeks later, after fasting for $16 \mathrm{hr}$. Metastatic nodules, $1 \mathrm{~mm}$ or less, were collected from liver and kidney respectively. Each specimen thus obtained was divided into two parts. One part was provided for pathohistological examination and another was injected with a small amount of $0.9 \% \mathrm{NaCl}$ solution into the peritoneal cavity of normal rats to make free cancer cells from each nodule, respectively. About 3 weeks later, each ascites was collected from each rat, while not bloody, and centrifuged at $4^{\circ} \mathrm{C}$ for $5 \mathrm{~min}(700 \times g)$. Each sediment was washed three times with Dulbecco's PBS without $\mathrm{Ca}^{2+}$ and $\mathrm{Mg}^{2+}(\mathrm{pH} 7.2$, Gibco, Long Island, NY, USA). Further details for obtaining intact metastatic cancer cells have been described elsewhere (Nakazawa and Iwaizumi 1982; 1989).

Experimental procedure. Metastatic cancer cells thus obtained and the control were suspended in Dulbecco's PBS mentioned above at the concentration of $2 \times 10^{7}$ cells per $1 \mathrm{ml}$. Then, $50 \mu \mathrm{l}$ of each cancer cell suspension ( $10^{6}$ cancer cells) was transferred into a glass screw vial $(4 \mathrm{ml})$ with silicon packing cap, and $50 \mu \mathrm{l}$ of the PBS containing $0.1 \mu \mathrm{Ci}$ of $\left(1{ }^{14} \mathrm{C}\right)$-AA (New England Nuclear, Boston, MA, USA) was added. After the mixture was incubated at $24^{\circ} \mathrm{C}$ for $3 \mathrm{~min}, 0.3 \mathrm{ml}$ of a solution consisting of ethyl acetate, methanol and $1 \mathrm{M}$ solution of citric acid $(30: 4: 1, \mathrm{v} / \mathrm{v})$ was added to each vial to stop the reaction. Afterwards, 0.5 $\mathrm{g}$ of anhydrous $\mathrm{Na}_{2} \mathrm{SO}_{4}$ was added to each vial and mixed violently using a mixer (Model TM-105, Thermonics, Tokyo), and $50 \mu 1$ of the supernatant was applied to Silicagel $\mathrm{F}_{254}$ glass plate $(20 \times 20 \mathrm{~cm}$, Art. 11798, Merck, Darmstadt, FRG). As authentic samples, AA (Merck), 6-keto-PGF $\mathrm{PG}_{1 \alpha}, \mathrm{PGF}_{2 \alpha}, \mathrm{PGE}_{2}, \mathrm{PGD}_{2}$ and $\mathrm{TXB}_{2}$ (Ono Pharmaceutical Co. Ltd., Osaka) were used. The plate was developed with a supernatant of a mixed solution of ethyl acetate, isooctane, acetic acid and distilled water $(90: 50: 20: 100, \mathrm{v} / \mathrm{v})$ at room temperature in a height of $15 \mathrm{~cm}$. After drying up in the atmosphere, the plate was developed again in the same solvent system, in order to separate $\mathrm{TXB}_{2}$ and $\mathrm{PGE}_{2}$. Then the plate was exposed to iodine vapor, and positions for authentic standards were marked, respectively. After that, each plate thus obtained was subjected to an autoradiography at $4^{\circ} \mathrm{C}$ for 2 weeks and each film was developed.

\section{Results and Discussion}

As shown in Fig. 1, a separation of $\mathrm{PGE}_{2}$ from $\mathrm{TXB}_{2}$ on the TLC plate was 


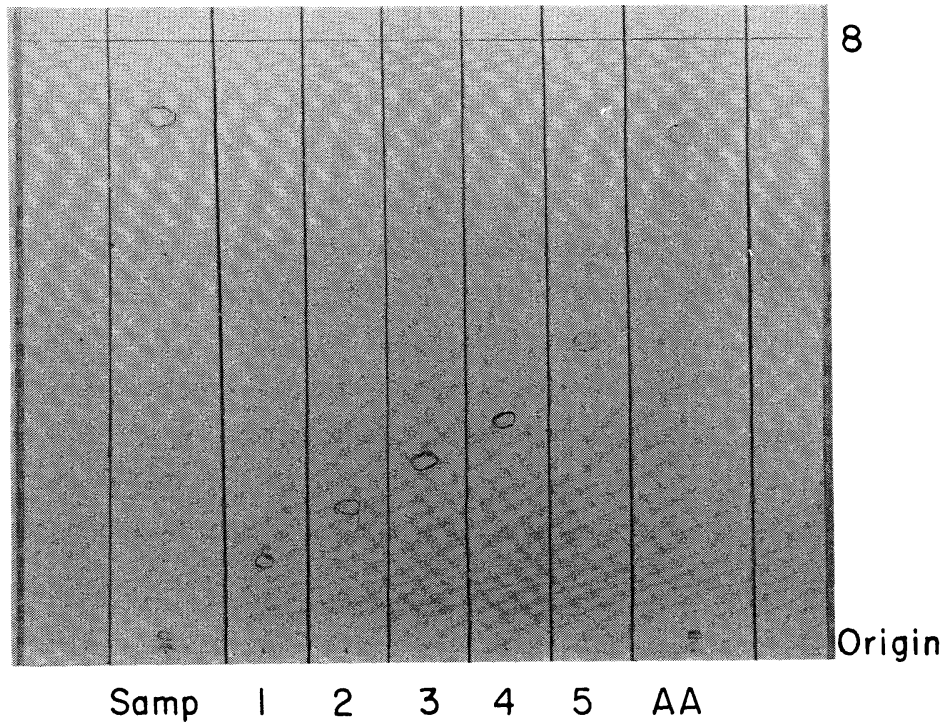

Fig. 1. Separation between authentic samples used in this study was well. Samp, sample applied to TLC ; 1, 6-keto- $\mathrm{PGF}_{1 \alpha} ; 2, \mathrm{PGF}_{2 \alpha} ; 3, \mathrm{TXB}_{2} ; 4, \mathrm{PGE}_{2} ; 5$, $\mathrm{PGD}_{2}$.

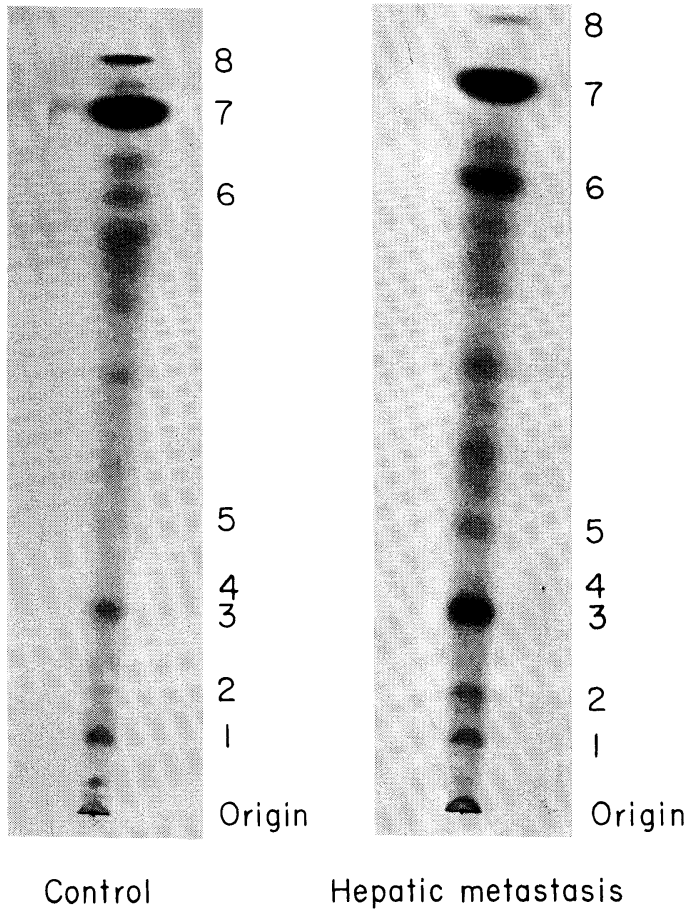

Fig. 2. Autoradiograms obtained from the hepatic metastatic and control cancer cells are presented. Abbreviation: Those of 1 to 5 are same with Fig. 1. 6 , an unidentified cyclooxygenase product; 7, AA (substrate); 8 , solvent front. 
relatively good, as well as that of other authentic samples used in this study. In the autoradiograms, as shown in Fig. 2, PG production ability of metastatic cancer cells was generally accelerated as compared with that of the control cells originally injected into left carotid artery of the rat. That is, $\mathrm{PG}$ production ability of the control was almost negligible except for 6-keto- $\mathrm{PGF}_{1 \alpha}$ and $\mathrm{TXB}_{2}$. Above all, $\mathrm{PGF}_{2 \alpha}$ production ability of metastatic cancer cells was quite remarkably accelerated as compared with that of the control. $\mathrm{PGF}_{2 \alpha}$ is one of the cell growth factors in Swiss 3T3 cells (Macphee et al. 1984), and enhances TPA promotion of skin tumors (Fischer et al. 1980). Thus, it seems that an accelerated $\mathrm{PGF}_{2 \alpha}$ production is closely related with cancer metastatic formation. Further study to clarify the causes of the accelerated $\mathrm{PGF}_{2 \alpha}$ production in the metastatic cancer cells would be helpful for elucidating the mechanism of cancer metastasis.

\section{Acknowledgments}

We wish to thank Emeritus Professor Haruo Sato and Professor Maroh Suzuki, Tohoku University, for the gift of AH100B cell and also for helpful advice and discussion. This work was suported in part by a Grant-in-Aid for General Scientific Research (58570303 and 01570375 to I. Nakazawa) from the the Ministry of the Education, Science and Culture of Japan.

\section{References}

1) Bosmann, H.B., Bieber, G.F., Brown, A.E., Case, K.R., Gesten, D.M., Kimmerer, T.W. \& Lione, A. (1973) Biochemical parameter correlated with tumor cell implantation. Nature (Lond.), 246, 487-489.

2) Fidler, I.J. (1973a) The relationship of embolic homogeneity, number, size, and viability to the incidence of experimental metastasis. Eur. J. Cancer, 9, 223-227.

3) Fidler, I.J. (1973b) Selection of successive tumor lines for metastasis. Nature, New Biol., 242, 148-149.

4) Fischer, S.M., Gleason, G.L., Hardin, L.G., Bohrman, J.S. \& Slaga, T.J. (1980) Prostaglandin modulation of phorbol ester skin tumor promotion. Carcinogenesis, $\mathbf{1}$, 245-248.

5) Macphee, C.H., Drummond, A.H., Otto, A.M. \& Asua, L.J. (1984) Prostaglandin F $_{2 \alpha}$ stimulates phosphatidylinositol turnover and increases the cellular content of 1, 2-diacylglycerol in confluent resting Swiss 3T3 cells. J. Cell Physiol., 119, 35-40.

6) Miller, W., David, O., Guinee, V., Imura, T., Nicolson, G. \& Cleary, K. (1985) Abscence of a relationship of size of primary colon carcinoma with the metastasis and survival. Clin. Exp. Metastasis, 3, 189-196.

7) Nakazawa, I. \& Iwaizumi, M. (1982) A correlation between cancer metastases and the fluidity of cancer cell membrane. Tohoku J. Exp. Med., 137, 325-328.

8) Nakazawa, I. \& Iwaizumi, M. (1989) A role of the cancer cell membrane fluidity in the cancer metastases: An ESR study. Tohoku J. Exp. Med., 157, 193-198.

9) Nakazawa, I., Ohtsuki, I. \& Goto, Y. (1978) The lipid-chemical features of the metastatic tissues into the liver from the human gastric cancer, large intestinal cancer and malignant insulinoma. Tohoku J. Exp. Med., 126, 95-101. 